Article

\title{
Impact of Groundwater Level on Nitrate Nitrogen Accumulation in the Vadose Zone Beneath a Cotton Field
}

\author{
Xiyun Jiao ${ }^{1,2}$, Arkin Maimaitiyiming 1,3, Mohamed Khaled Salahou 1,2,*, Kaihua Liu ${ }^{1,2}$ and \\ Weihua Guo ${ }^{2}$ \\ 1 State Key Laboratory of Hydrology-Water Resources and Hydraulic Engineering, Hohai University, \\ Nanjing 210098, China; xyjiao@hhu.edu.cn (X.J.); 151302060007@hhu.edu.cn (A.M.); \\ 150402060005@hhu.edu.cn (K.L.) \\ 2 College of Water Conservancy and Hydropower Engineering, Hohai University, Nanjing 210098, China; \\ 20140058@hhu.edu.cn \\ 3 Station of General of Water Resources Panning in Agricultural and Pastoral Area of the Xinjiang Uyghur \\ Autonomous Region, Urumqi 830001, China \\ * Correspondence: salahou3@hotmail.com or msalahou@gmail.com; Tel.: +86-138-1408-0907
}

Academic Editor: Arjen Y. Hoekstra

Received: 27 July 2016; Accepted: 24 February 2017; Published: 28 February 2017

\begin{abstract}
In this study, the impacts of groundwater level on nitrate nitrogen accumulation in the vadose zone of a cotton field were investigated. Experiments were conducted in a cotton field at the CAS Ecological Agricultural Experiment Station in Nanpi from 2008 to 2010. A vertical observation well was drilled, and time-domain reflectometry probes and soil solution extractors were installed every $50 \mathrm{~cm}$ in the walls of the well to a depth of $5 \mathrm{~m}$. The soil water content was monitored, and soil solution samples were obtained and analyzed every six days throughout the growing seasons during the three studied years. Additionally, a water consumption experiment was conducted, and the topsoil water content and leaf area index were measured in the cotton field. The resulting data were used to estimate parameters for use in a soil hydraulic and nitrate nitrogen movement model, and cotton evapotranspiration was calculated using the Penman-Monteith method. Groundwater level increases and decreases of $\pm 4 \mathrm{~m}$ were simulated during a ten-year period using HYDRUS-1D. The results showed significant nitrate nitrogen accumulation in the vadose zone when the groundwater level remained unchanged or decreased, with increased accumulation as the groundwater depth increased. Additionally, increased precipitation and a deeper groundwater level resulted in greater nitrate nitrogen leaching in the cotton root zone. Therefore, irrigation and fertilization strategies should be adjusted based on precipitation conditions and groundwater depth.
\end{abstract}

Keywords: groundwater depth; vadose zone; nitrate nitrogen; accumulation; situation-based simulation

\section{Introduction}

The imbalance in the supply and demand of water resources in the Haihe River Basin in northern China has become increasingly acute, and the per capita water availability is $270 \mathrm{~m}^{3}$ per annum. The Heilonggang Basin in Hebei Province, China, is a typical sub-basin of the Haihe Basin. Heilonggang is a drought- and flood-prone coastal alluvial plain. Since the 1970s, groundwater levels have declined as a result of climate change, human activities [1] and increased demands for water [2], resulting in the formation of a perennial shallow groundwater depression cone over a wide area. This cone is still expanding and has triggered problems such as land subsidence [3]. The rate of groundwater level decline in this region was particularly high from 1970 to 1981 and relatively constant after 1981 [4]. Recently, mitigation measures such as restricting agricultural water use, improving water recharge 
and implementing measures to control the groundwater level and allow it to rebound have been implemented [5]. The groundwater level fluctuations throughout the year are relatively high because of precipitation, evaporation and the timing of groundwater extraction. Generally, the groundwater level decreases from March to June and rebounds from June to September. From October to February, the groundwater level remains relatively stable [6]. During wet years, the groundwater level after the flood season can reach up to $2 \mathrm{~m}$ higher than the minimum groundwater level before the flood season [7].

Hebei Province is an important province for cotton production in China. The total cotton yield decreased from 570,800 tons per annum in 1990 to 222,600 tons per annum in 1999 and then gradually increased to 631,000 tons per annum in 2006 [8]. In order to increase the crop production, excess amount of agriculture fertilizer is applied in the winter wheat, maize and cotton cropping systems on the North China Plain. Such a process results in nitrate nitrogen concentrations in excess of $10 \mathrm{mg} \cdot \mathrm{L}^{-1}$ in the shallow groundwater below the North China Plain $[9,10]$, which is the limit for potable water adopted in the US and Canada [11,12]. Research indicates that agricultural practices are the primary source of excess nitrate nitrogen [13] due to the crop uptake of over-applied nitrogen fertilizers [10,14] and conventional tillage practices [15]. Additionally, nitrate nitrogen concentrations can be influenced by rainfall [15], with excess nitrogen accumulating in the soil vadose zone or leaching into the groundwater [16] because the $\mathrm{NH}_{4}{ }^{+}$from ammonium compounds is easily adsorbed by soil particles and $\mathrm{NO}_{2}{ }^{-}$is unstable [17]. For these reasons, monitoring the nitrate in the soil vadose zone is important in studies of groundwater contamination [18] .Furthermore, excess nitrogen that is not absorbed by crops is retained in the vadose zone or leached into the groundwater $[19,20]$. The thickness of the aeration zone changes as the groundwater level changes, which affects soil water and solute transport [21]. Selecting the optimum nitrogen use and irrigation rate can reduce nitrate nitrogen losses, improve the nitrogen use efficiency and decrease groundwater nitrate pollution on the North China Plain [22]. Hence, the distribution and transport of nitrate nitrogen based on agricultural irrigation has been studied in South China [23] and North China [24].

Various methods have been presented for determining and monitoring nitrate nitrogen concentrations in groundwater to provide guidance for the development of water quality management strategies [25], identify trends in groundwater nitrate concentrations and prevent further groundwater quality deterioration [26]. Researchers have suggested that both shallow and deep groundwater chemistry should be monitored and that the recharge areas associated with regional flow systems are extremely vulnerable to nitrate pollution [27]. Additionally, nitrates accumulate quickly in groundwater, and most nitrates remain in the soil, even after leaching due to large amounts of rain [28].

The previous studies investigated the problems of nitrate nitrogen contamination in the vadose zone and in the groundwater. Selecting the optimum nitrogen fertilization rates was also investigated. However, the effects of the groundwater fluctuations in the vadose zone on the distribution and amount of nitrate nitrogen were not well addressed. Hence, this paper presents a primary study of the impacts of groundwater level changes on the nitrate nitrogen concentrations in the vadose zone of a cotton field based on a scenario analysis in the Heilonggang Basin, Hebei Province, China. In addition, the following questions concerning the fate of nitrate nitrogen in the vadose zone were addressed: (i) How does the groundwater level affect the accumulation of nitrate nitrogen in the vadose zone? (ii) Do precipitation and the groundwater level at the soil depth of cotton roots affect the amount of nitrate leaching with respect to different irrigation and fertilization levels?

\section{Study Area and Data Processing}

Field studies were conducted at the CAS Ecological Agricultural Experiment Station in the town of Nanpi, Hebei Province, China, at a longitude, latitude and elevation of $116^{\circ} 40^{\prime} \mathrm{E}, 38^{\circ} 06^{\prime} \mathrm{N}$ and $20 \mathrm{~m}$, respectively (Figure 1). The mean annual evaporation and precipitation at the study site are $1334 \mathrm{~mm}$ (E601 evaporator observations) and $567.4 \mathrm{~mm}$, respectively. A field with an area of $319.9 \mathrm{~m}^{2}$ was 
planted with cotton in late April and harvested in late October during the three experimental years of 2008,2009 and 2010. The site contained silt loam soil and had a groundwater depth of approximately $4 \mathrm{~m}$. The volumetric soil water content at field capacity before irrigation ranged from $15.8 \%$ to $19.6 \%$, and the average bulk density was $1.40 \mathrm{~g} \cdot \mathrm{cm}^{-3}$ at a soil depth of $1 \mathrm{~m}$ (Table 1 ).

Table 1. Physical soil properties at the experimental site.

\begin{tabular}{|c|c|c|c|c|c|}
\hline \multirow{2}{*}{ Soil Layer (cm) } & \multicolumn{3}{|c|}{ Particle Size Distribution (\%) } & \multirow{2}{*}{ Texture U.S. } & \multirow{2}{*}{ Bulk Density $\left(\mathrm{g} \cdot \mathrm{cm}^{-3}\right)$} \\
\hline & Sand & Silt & Clay & & \\
\hline $0-20$ & 11.84 & 66.21 & 21.95 & Powder Soil & 1.40 \\
\hline $20-40$ & 11.84 & 66.21 & 21.95 & Powder Soil & 1.40 \\
\hline $40-60$ & 11.84 & 66.21 & 21.95 & Powder Soil & 1.40 \\
\hline $60-110$ & 11.84 & 66.21 & 21.95 & Powder Soil & 1.40 \\
\hline $110-170$ & 11.84 & 66.21 & 21.95 & Powder Soil & 1.40 \\
\hline $170-275$ & 21.31 & 66.77 & 11.93 & Powder Soil & 1.43 \\
\hline $275-450$ & 26.57 & 50.11 & 23.32 & Powder Soil & 1.44 \\
\hline $450-600$ & 85.54 & 10.43 & 4.03 & Sandy Soil & 1.20 \\
\hline $450-850$ & 85.54 & 10.43 & 4.03 & Sandy Soil & 1.20 \\
\hline $850-1100$ & 85.54 & 10.43 & 4.03 & Sandy Soil & 1.20 \\
\hline
\end{tabular}

An observation well in the middle of the cotton field was used to monitor groundwater depth, soil water content and solute concentrations. Time-domain reflectometry (TDR) probes and soil solution extractors were installed vertically every $50 \mathrm{~cm}$ in the wall of the well to a depth of $5 \mathrm{~m}$ (Figure 2). The soil water content was monitored, and soil solution samples were obtained and analyzed every six days throughout the growing seasons during the three studied years.

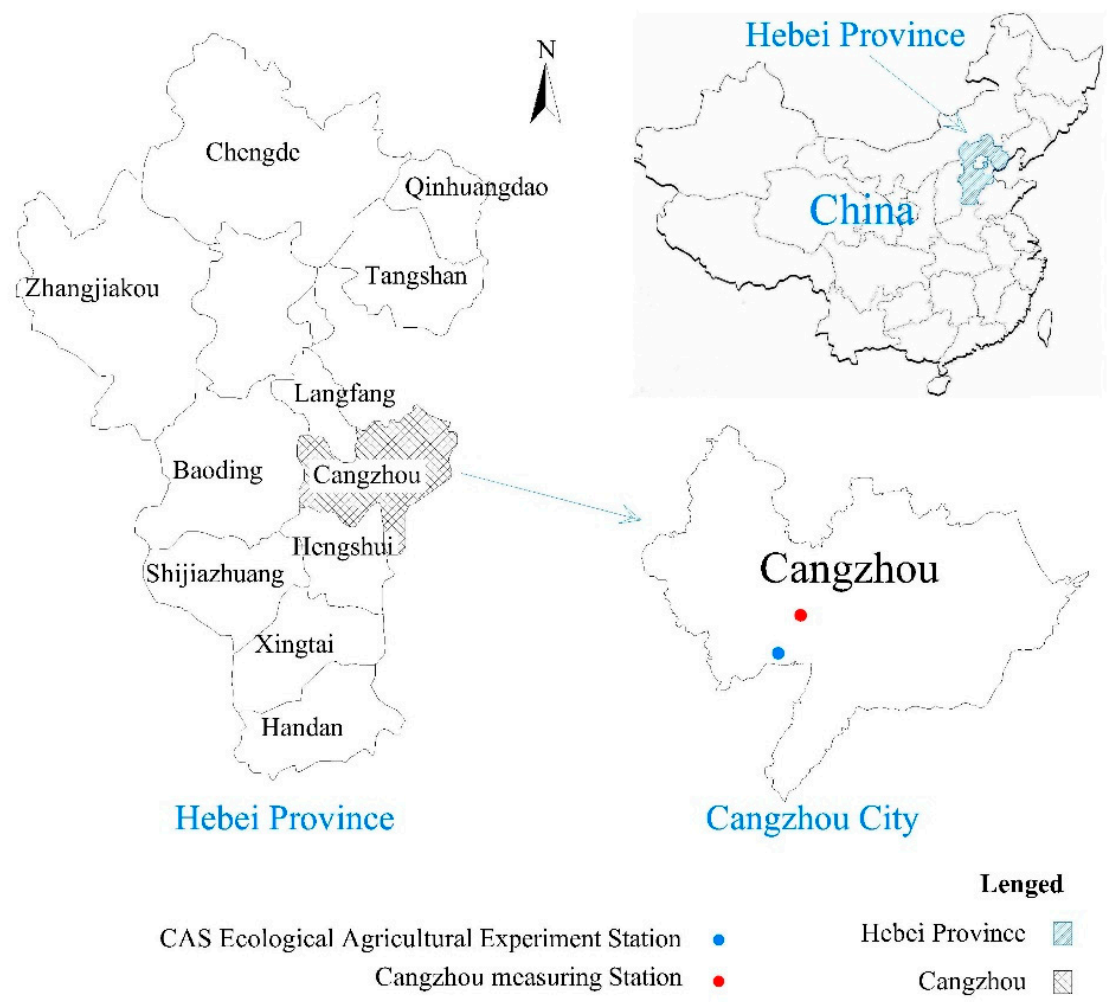

Figure 1. Location of the experimental and measuring stations in Changzhou, Hebei Province, China. 


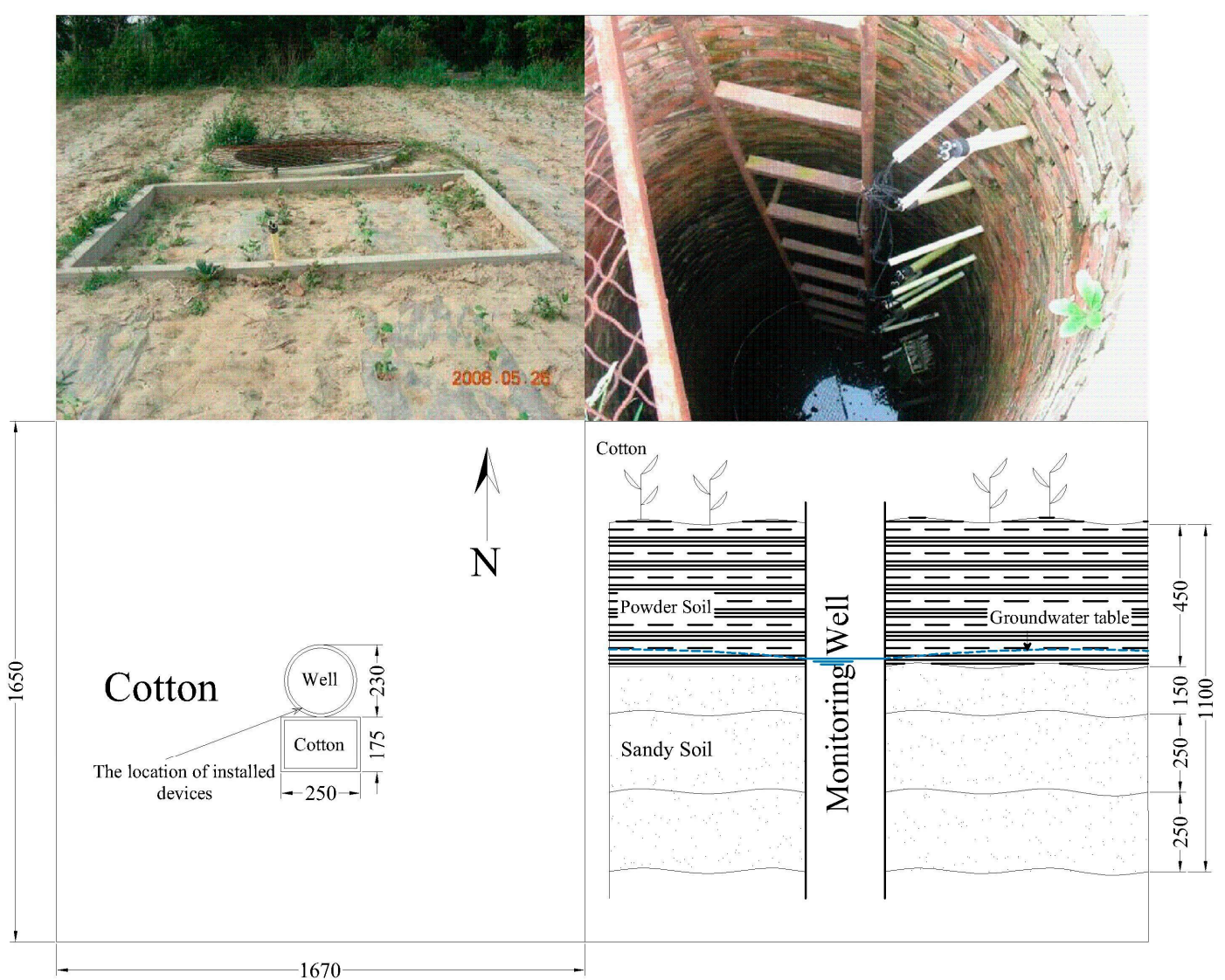

Figure 2. Plan and schematic cross-section of a field site with a monitoring well with dimensions given in $\mathrm{cm}$.

\section{Methodology}

The transport model parameters for soil water and fertilizer were calibrated for three types of groundwater level scenario-based simulations over a projected period of 10 years (2011-2020). The boundary conditions and the accumulation of nitrate nitrogen in the vadose zone simulated conventional tillage to provide a basis for improving the nitrogen use efficiency and reducing groundwater pollution. The complete methodology applied for the present work is shown in the flowchart (Figure 3).

\subsection{The Model and Parameters}

The HYDRUS-1D model, developed by the United States Salinity Laboratory, was used in this study. The Richards equation was used to simulate soil water calculations, and the convection-diffusion equation was used for the solute simulation. Many applications indicate that the model can precisely simulate water and nitrogen processes in soil-plant systems involving continuous loops of water and nitrogen use [29].

The soil-water characteristic curve uses the van Genuchten and Mualem models [30,31]:

$$
\begin{gathered}
S_{e}=\frac{\theta-\theta_{r}}{\theta_{s}-\theta_{r}}=\left[\frac{1}{1+(\alpha h)^{n}}\right]^{m} \\
K=K_{s} \frac{\left[1-(\alpha h)^{n-1}\left[1+(\alpha h)^{n}\right]^{m}\right]^{2}}{\left[1+(\alpha h)^{n}\right]^{\frac{m}{2}}}
\end{gathered}
$$


where $S_{e}$ is the effective saturation, $n$ is an empirical constant that affects the shape of the curve, $m=1-(1 / n), \alpha$ is an empirical parameter that is often referred to as the inverse of the air entry point $\mathrm{cm}^{-1}, \theta$ is the soil water content in $\mathrm{cm}^{3} \cdot \mathrm{cm}^{-3}, \theta_{r}$ is the residual moisture content in $\mathrm{cm}^{3} \cdot \mathrm{cm}^{-3}$, $\theta_{s}$ is the saturated water content in $\mathrm{cm}^{3} \cdot \mathrm{cm}^{-3}, \mathrm{~h}$ is the soil water suction head in $\mathrm{cm}, K$ is the unsaturated hydraulic conductivity at a certain water content or pressure head, and $K_{S}$ is the saturated hydraulic conductivity.

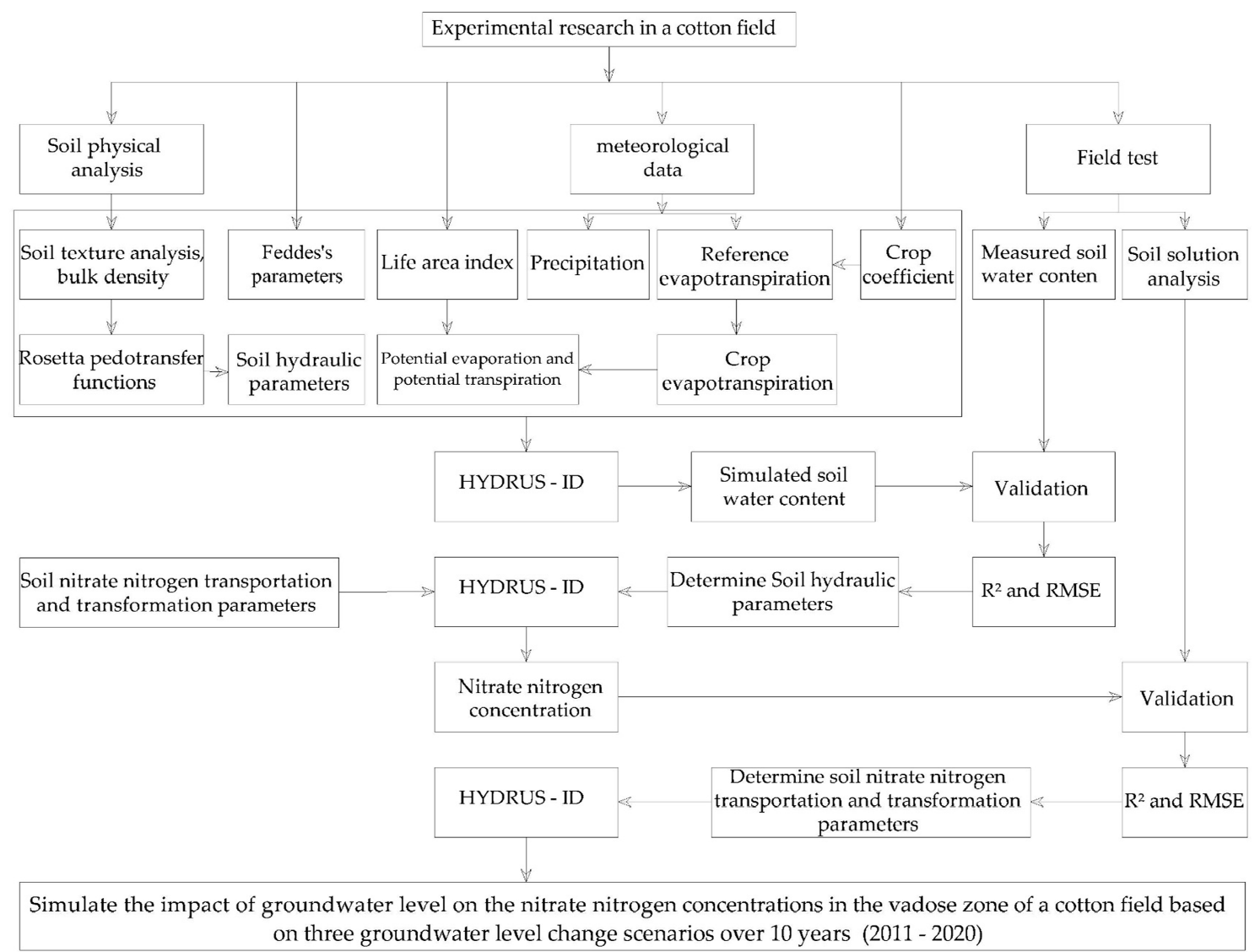

Figure 3. Flowchart of the outline of the methodology.

The van Genuchten parameters and the saturated hydraulic conductivity were obtained via Rosetta pedotransfer functions (PTFs) [32] using the particle size distribution and bulk density datasets in the HYDRUS-1D model. The best parameter values $\left(K_{s}, \theta_{s}, \theta_{r}, \alpha\right.$ and $\left.n\right)$ were obtained using inverse simulations after several iterations until the maximum change between observed and simulated soil water content was less than a specified tolerance.

The agreement between the observed and simulated data was evaluated using the coefficient of determination $\left(R^{2}\right)$ and root mean standard error (RMSE):

$$
\begin{gathered}
R^{2}=1-\frac{\sum_{i=1}^{N}\left(P_{i}-O_{i}\right)^{2}}{\sum_{i=1}^{N}\left(O_{i}-O_{\text {ave }}\right)^{2}} \\
\text { RMSE }=\sqrt{\frac{\sum_{i=1}^{N}\left(O_{i}-p_{i}\right)^{2}}{N}}
\end{gathered}
$$


where $P_{i}$ represents the predicted values, $O_{i}$ represents the observed values, $O_{\text {ave }}$ is the mean value of all observed events and $N$ is the number of observations. The $R^{2}$ and RMSE values were 0.91 and $0.026 \mathrm{~cm}^{3} \cdot \mathrm{cm}^{-3}$, respectively, which indicates that the accuracy of the model simulation was acceptable (Figure 4). The resulting parameter values from June to November 2009 are shown in Table 2.
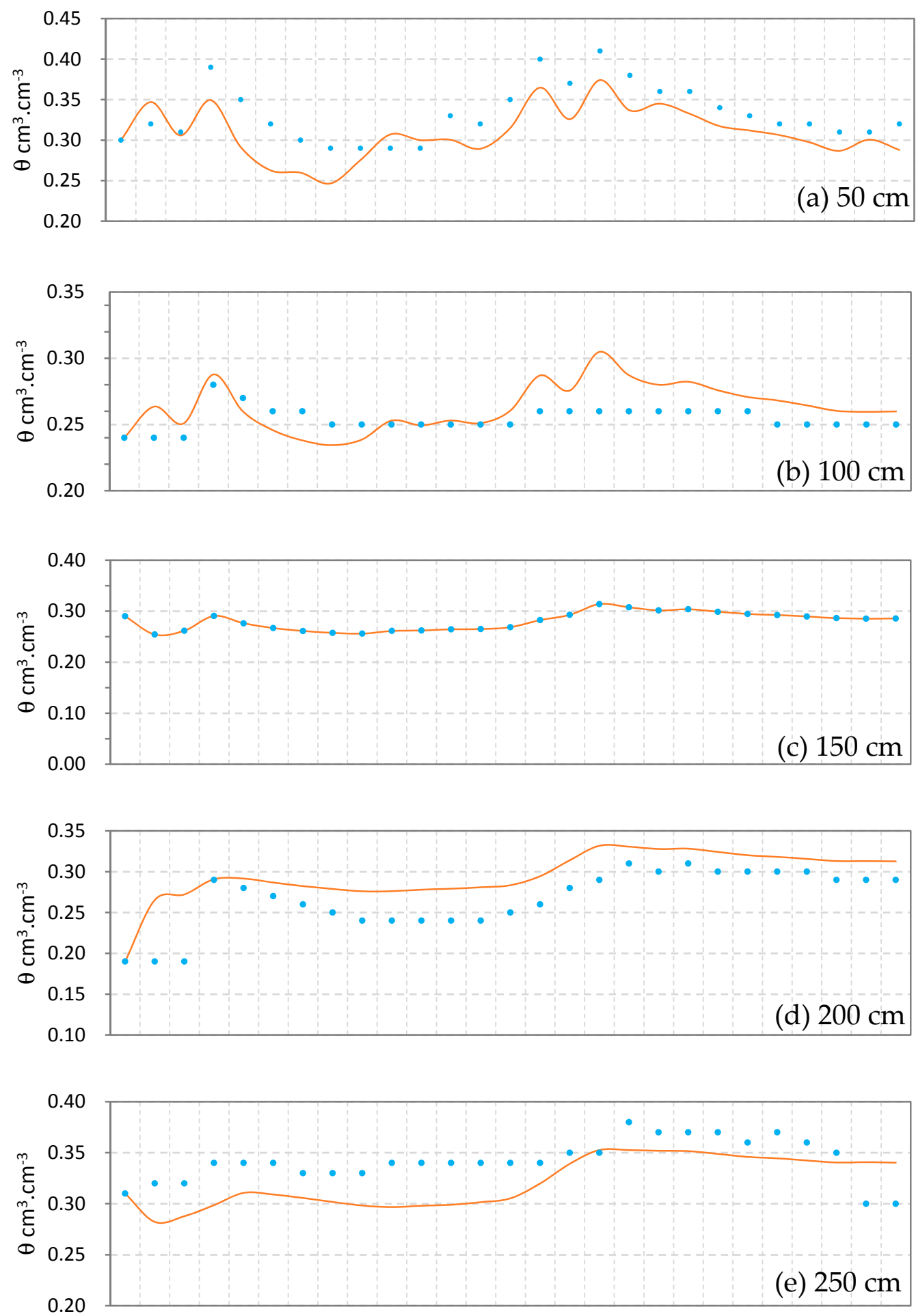

Figure 4. Cont. 

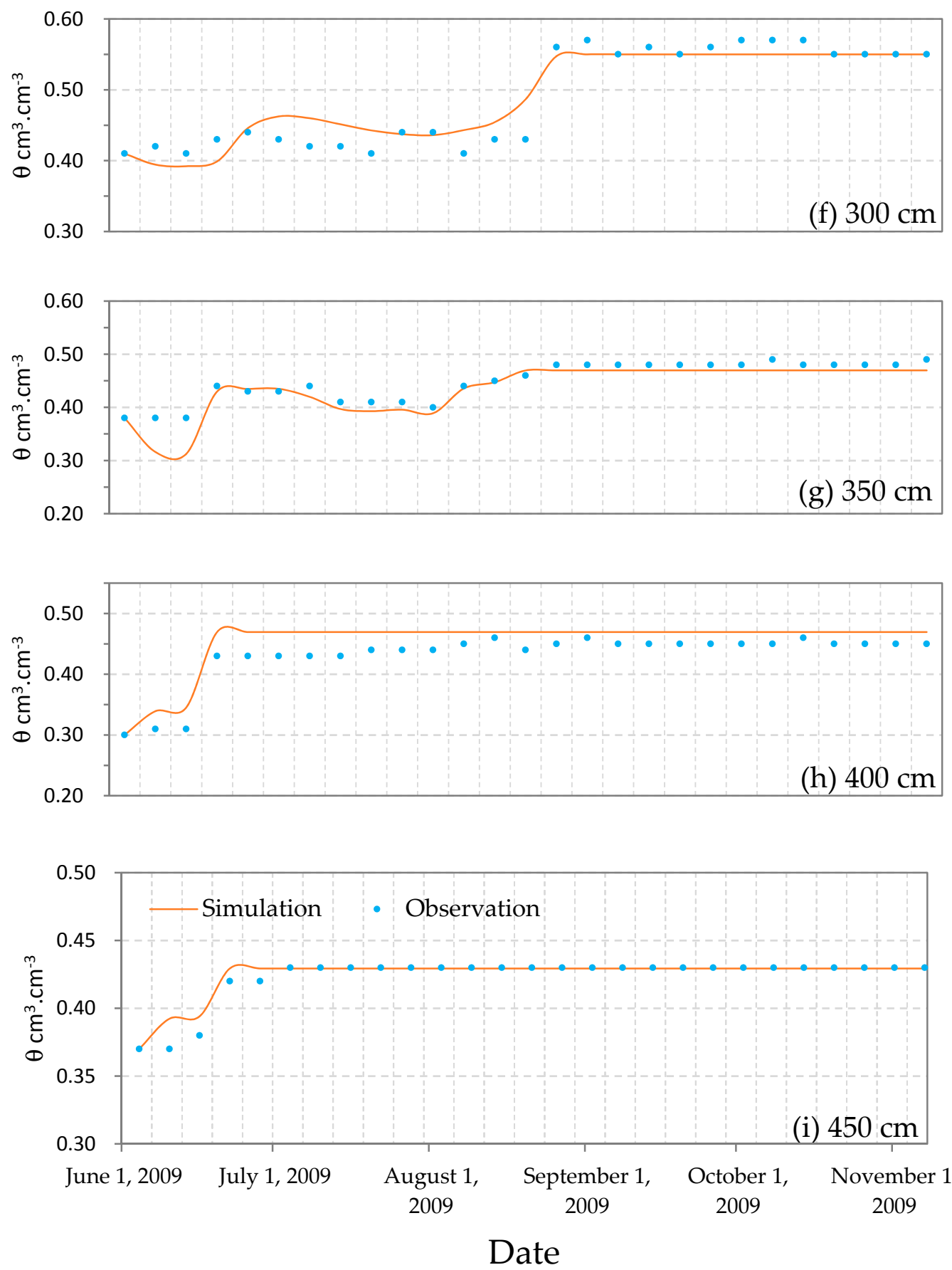

Figure 4. Measured (dots) and simulated (lines) volumetric soil water contents at depths of (a) 50, (b) 100, (c) 150, (d) 200, (e) 250, (f) 300, (g) 350, (h) 400, and (i) $450 \mathrm{~cm}$ from June to November 2009.

The ammonium nitrogen that formed after the field was fertilized was assumed to rapidly transform into nitrate. Immobilization, denitrification and mineralization were all calculated according to a first-order kinetics model, which is simple chemical non-equilibrium model that assumes sorption is a kinetic process implemented into HYDRUS-1D [33-35]. Table 3 shows the results based on data from 4 June to 12 November 2009, the inverse nitrate nitrogen transport calculation results and the transformation parameters in different soil layers. The $R^{2}$ and RMSE values of the nitrate nitrogen concentration were 0.70 and $0.0078 \mathrm{mg} \cdot \mathrm{cm}^{-3}$, respectively (Figure 5). 
Table 2. Soil moisture parameters of the van Genuchten-Mualem model for different soil horizons at the experimental site.

\begin{tabular}{cccccc}
\hline Soil Layer $(\mathbf{c m})$ & $\theta_{r}\left(\mathbf{c m}^{\mathbf{3}} \cdot \mathbf{c m}^{-3}\right)$ & $\theta_{s}\left(\mathbf{c m}^{\mathbf{3}} \cdot \mathbf{c m}^{-\mathbf{3}}\right)$ & $\boldsymbol{\alpha}\left(\mathbf{c m}^{-\mathbf{1}}\right)$ & $n(\mathbf{- )}$ & $\boldsymbol{K}_{\boldsymbol{s}}\left(\mathbf{c m} \cdot \mathbf{D a y}^{-\mathbf{1}}\right)$ \\
\hline $0-20$ & 0.1000 & 0.41 & 0.0032 & 1.8026 & 2.63 \\
$20-40$ & 0.1000 & 0.41 & 0.0032 & 1.8026 & 2.63 \\
$40-60$ & 0.1000 & 0.41 & 0.0032 & 1.8026 & 2.63 \\
$60-110$ & 0.1000 & 0.41 & 0.0032 & 1.8026 & 2.63 \\
$110-170$ & 0.1000 & 0.41 & 0.0032 & 1.8026 & 2.63 \\
$170-275$ & 0.0181 & 0.47 & 0.0316 & 1.4555 & 71.99 \\
$275-450$ & 0.0447 & 0.50 & 0.0178 & 1.6502 & 27.10 \\
$450-600$ & 0.0675 & 0.46 & 0.0241 & 1.7879 & 94.65 \\
$600-850$ & 0.0675 & 0.46 & 0.0241 & 1.7879 & 94.65 \\
$850-1100$ & 0.0675 & 0.46 & 0.0241 & 1.7879 & 94.65 \\
\hline
\end{tabular}

Table 3. Soil nitrate nitrogen transportation and transformation parameters.

\begin{tabular}{|c|c|c|c|c|c|}
\hline $\begin{array}{l}\text { Soil Layer } \\
(\mathrm{cm})\end{array}$ & $\begin{array}{c}\text { Free Water Diffusion } \\
\text { Coefficients } \\
\left(\mathrm{cm}^{2} \cdot \text { Day }^{-1}\right)\end{array}$ & $\begin{array}{l}\text { Dispersion } \\
\text { Coefficient } \\
\quad(\mathrm{cm})\end{array}$ & $\begin{array}{c}\text { Mineralization Rate } \\
\text { Constant } \\
\left(\mathrm{mg} \cdot \mathrm{cm}^{-3} \cdot \mathrm{Day}^{-1}\right)\end{array}$ & $\begin{array}{l}\text { Immobilization } \\
\text { Constant } \\
\left(\text { Day }^{-1}\right)\end{array}$ & $\begin{array}{c}\text { Denitrification } \\
\text { Rate Constant } \\
\left.\text { (Day }^{-1}\right)\end{array}$ \\
\hline $0-20$ & 2.14 & 4.5 & 0.2 & 0.004 & 0.005 \\
\hline $20-40$ & 2.14 & 4.5 & 0.2 & 0.003 & 0.004 \\
\hline $40-60$ & 2.14 & 4.5 & 0.1 & 0.002 & 0.003 \\
\hline $60-110$ & 2.14 & 4.5 & 0.05 & 0.001 & 0.001 \\
\hline 110-170 & 2.14 & 4.5 & 0.05 & 0.0009 & 0 \\
\hline $170-275$ & 2.14 & 3.5 & 0.05 & 0.0007 & 0 \\
\hline 275-450 & 2.14 & 3.6 & 0 & 0.0003 & 0 \\
\hline $450-600$ & 2.14 & 5.2 & 0 & 0 & 0 \\
\hline $600-850$ & 2.14 & 5.2 & 0 & 0 & 0 \\
\hline $850-1100$ & 2.14 & 5.2 & 0 & 0 & 0 \\
\hline
\end{tabular}

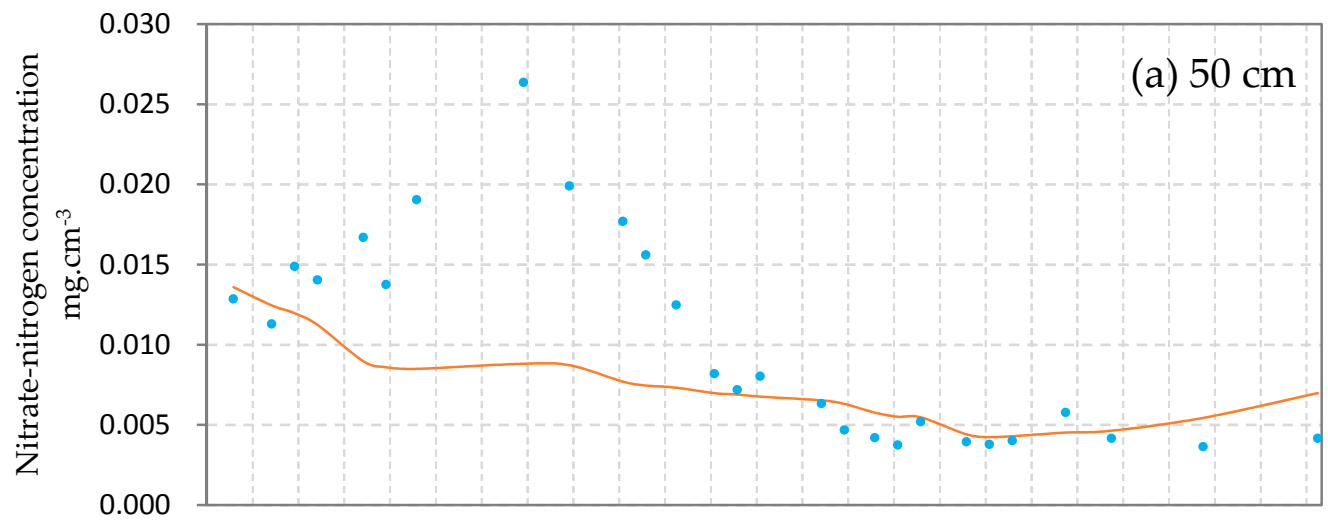

Figure 5. Cont. 

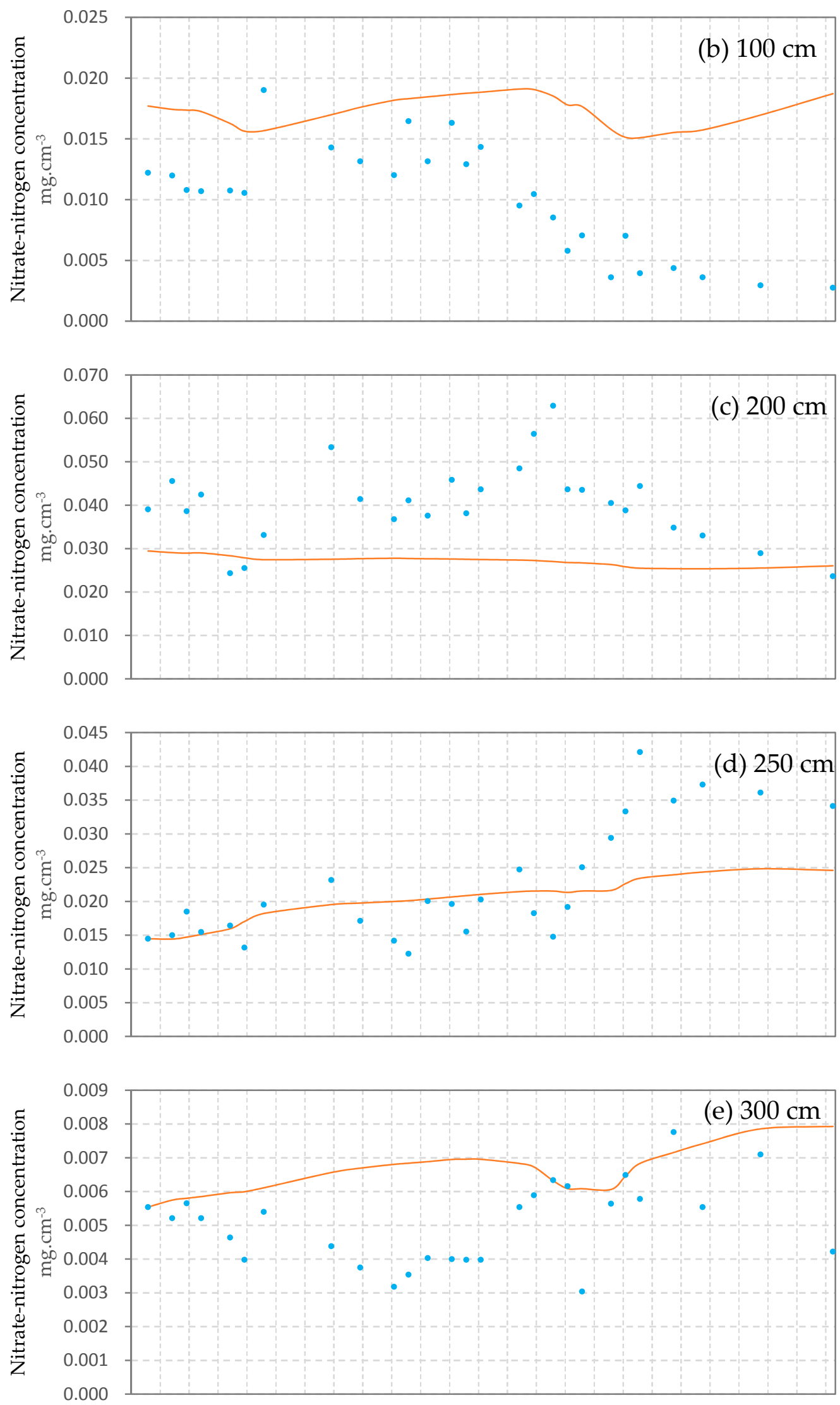

Figure 5. Cont. 


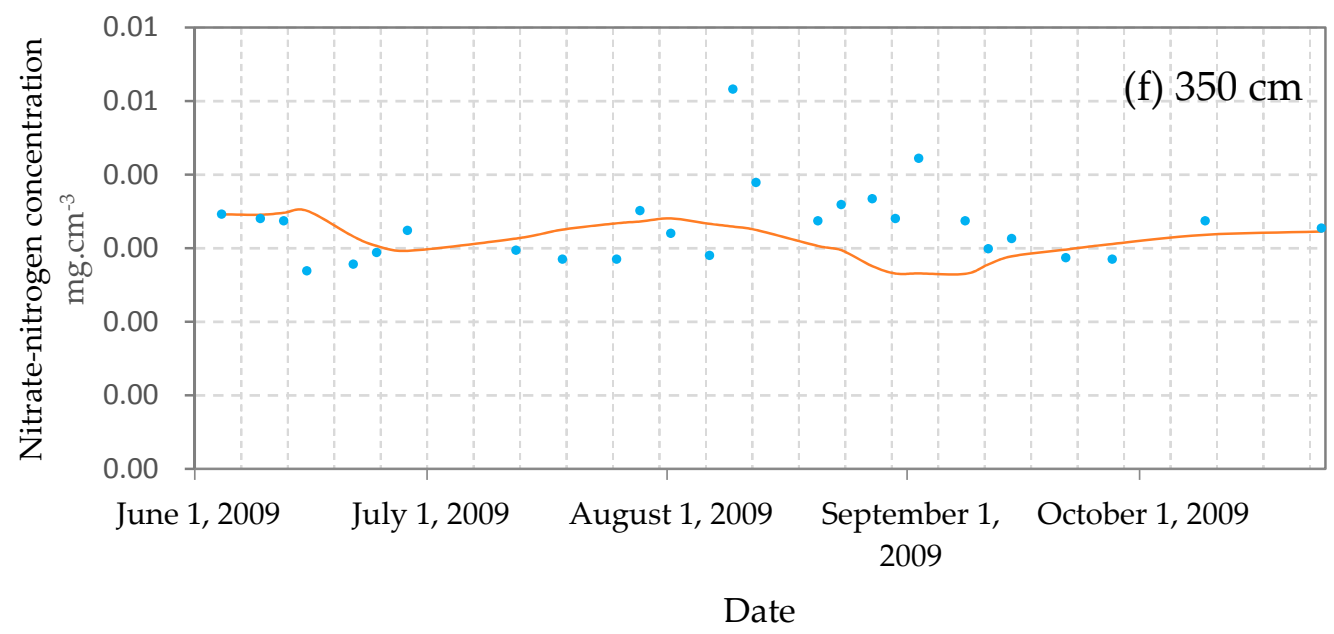

Figure 5. Measured (dots) and simulated (lines) nitrate nitrogen concentrations at depths of (a) 50, (b) 100, (c) 200, (d) 250, (e) 300 and (f) $350 \mathrm{~cm}$ from June to November 2009.

\subsection{Precipitation}

The yearly average precipitation in the experimental area is $567.4 \mathrm{~mm}$. Rainfall generally occurs during the summer, with $73 \%, 11 \%, 13 \%$ and $3 \%$ of the annual precipitation occurring in the summer, spring, autumn and winter, respectively. Precipitation data for this region are available from the Changzhuang measuring station located near the experimental site $\left(116^{\circ} 51^{\prime} \mathrm{E}, 38^{\circ} 21^{\prime} \mathrm{N}\right)$ (Figure 1) for 55 years from 1954 to 2008. Precipitation data from 1988 to 1997 were considered a typical ten-year series for a statistical parameter stability analysis of the coefficient of variation $(\mathrm{Cv})$ and skewness $(\mathrm{Cs})$. The results are shown in Figure 6.

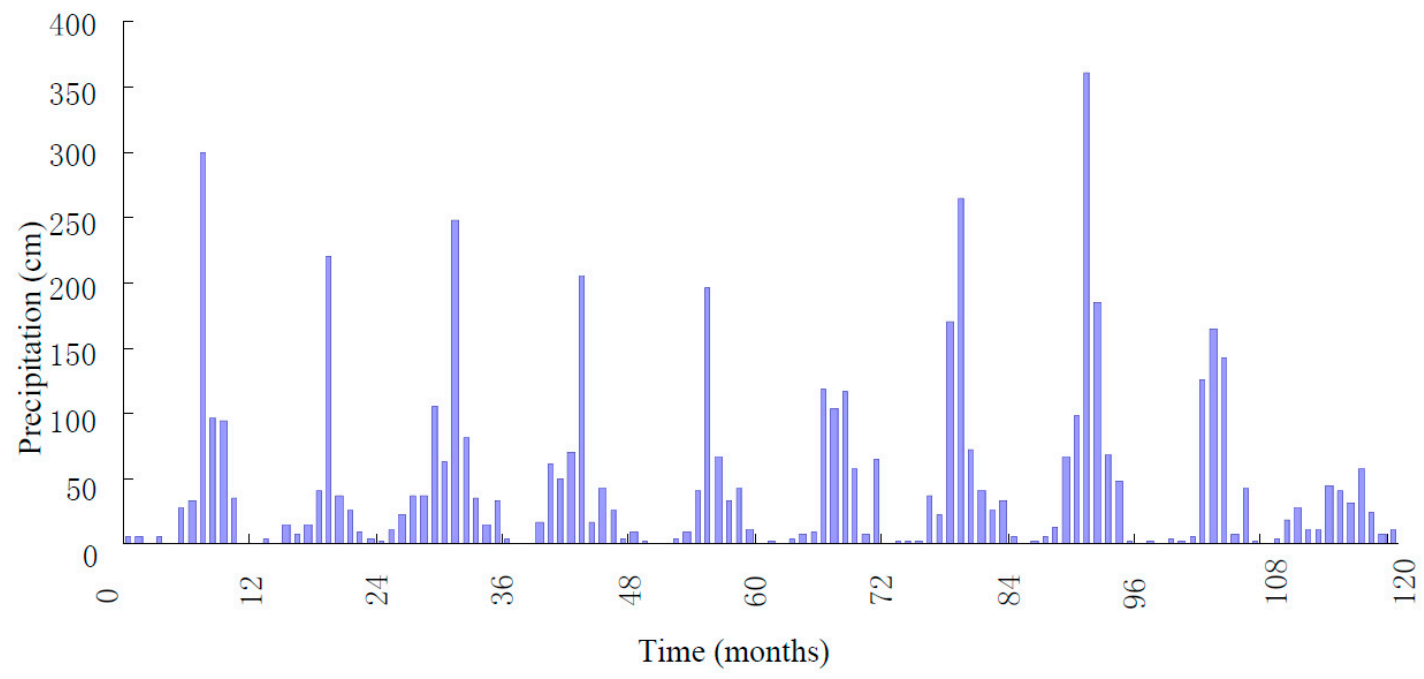

Figure 6. Monthly precipitation in a ten-year series from 1988 to 1997.

\subsection{Irrigation and Fertilization}

A cultivated cotton crop was analyzed in this study. Flood irrigation was conducted one week before seeding each growing season. The total amount of irrigation water applied outside of the growing season was $750 \mathrm{~m}^{3} \cdot \mathrm{hm}^{-2}$; the traditional amount of basal fertilizer applied during common farming practices in the study area was $750 \mathrm{~kg} \cdot \mathrm{hm}^{-2}$; and the N, P and $\mathrm{K}$ contents were all $15 \%$. The basal fertilizer was directly applied in the field before sowing each growing season. In general, the rate of $\mathrm{N}$ loss ranged from $20 \%$ to $25 \%$ and was considered $25 \%$ in this study. 
The soil water retention of the field in the crop root zone was $0.342 \mathrm{~cm} \cdot \mathrm{cm}^{-3}$. Additionally, the water holding capacity of the field was $65 \%$ and was considered the soil water content of the lower limit of the cotton root zone and used to formulate the crop irrigation system.

\subsection{Evapotranspiration and Bare Soil Evaporation}

Crop evapotranspiration is equal to the crop coefficient multiplied by the reference evapotranspiration (RET). It is difficult to measure RET directly; in most cases, RET is estimated using meteorological records. The most reliable method for diverse climates is the FAO56 Penman-Monteith (PM) method because it is physically based and explicitly incorporates both physiological and aerodynamic parameters [36]. The PM method requires sunshine duration, temperature, humidity and wind speed data and can be given in the following form [37]:

$$
\begin{gathered}
\text { RET }=\frac{0.408 \Delta\left(R_{n}-G\right)+\gamma\left[\frac{900}{T+273}\right] u_{2}\left(e_{s}-e_{a}\right)}{\Delta+\gamma\left(1+0.34 u_{2}\right)} \\
\text { ET }=K_{c} \times \text { RET }
\end{gathered}
$$

where RET is the reference evapotranspiration $\left(\mathrm{mm} \cdot \mathrm{day}^{-1}\right), R_{n}$ is the net radiation at the crop surface $\left(\mathrm{MJ} \cdot \mathrm{m}^{-2} \cdot\right.$ day $\left.^{-1}\right), \mathrm{G}$ is the soil heat flux density $\left(\mathrm{MJ} \cdot \mathrm{m}^{-2} \cdot \mathrm{day}^{-1}\right), T$ is the mean daily air temperature $\left({ }^{\circ} \mathrm{C}\right), u_{2}$ is the mean daily wind speed at $2 \mathrm{~m}$ above the ground level $\left(\mathrm{m} \cdot \mathrm{s}^{-1}\right), e_{\mathrm{s}}$ is the saturation vapor pressure $(\mathrm{kPa}), e_{\mathrm{a}}$ is the actual vapor pressure $(\mathrm{kPa}), e_{\mathrm{S}}-e_{\mathrm{a}}$ is the saturation vapor pressure deficit $(\mathrm{kPa}), \Delta$ is the slope of the saturated vapor pressure in relation to the air temperature $\left(\mathrm{kPa} \cdot{ }^{\circ} \mathrm{C}^{-1}\right)$, $\gamma$ is a psychrometric constant $\left(\mathrm{kPa} \cdot{ }^{\circ} \mathrm{C}^{-1}\right)$, ET is the actual crop evapotranspiration $\left(\mathrm{mm} \cdot \mathrm{day}^{-1}\right)$ and $K_{c}$ is the crop coefficient. The crop coefficient values were estimated using the observed weighing lysimeter data. Detailed descriptions of the functions, structures, and principles were provided by Yang et al. [38]. Table 4 shows the crop coefficient values.

Table 4. Crop coefficients $(K c)$.

\begin{tabular}{cccccccc}
\hline \multirow{2}{*}{ April } & \multirow{2}{*}{ May } & \multirow{2}{*}{ June } & \multicolumn{2}{c}{ July } & \multirow{2}{*}{ August } & \multirow{2}{*}{ September } & October \\
\cline { 4 - 5 } & & & Early & Late & & & \\
\hline 0.38 & 0.40 & 0.52 & 0.80 & 1.00 & 1.12 & 1.00 & 0.58 \\
\hline
\end{tabular}

Then, ET was divided into potential evaporation $\left(E_{p}\right)$ and potential transpiration $\left(T_{p}\right)$ [39]:

$$
\begin{gathered}
E_{p}=\left\{\begin{array}{lc}
\mathrm{ET} \times(1-0.43 L A I) & L A I \leq 1.0 \\
\mathrm{ET} \times e^{-0.4 \times L A I} & L A I \geq 1.0
\end{array}\right\} \\
T_{p}=\mathrm{ET}-E_{p}
\end{gathered}
$$

where $L A I$ (Leaf area index) is defined as the ratio of the leaf area to land area in units $\mathrm{of}^{2} \cdot \mathrm{cm}^{-2}$. The LAI was calculated by summing the leaf area per plant (measured using an AM300 area meter) and multiplying that total by an empirical factor of 0.74 [40] and the total number of plants ( 24 rows $\times 56$ plants per row). This value was then divided by the total planted area $\left(319.9 \mathrm{~m}^{2}\right)$ (Table 5). 
Table 5. Cotton leaf area index.

\begin{tabular}{cccccccccccc}
\hline \multirow{2}{*}{ Cotton Leaf Area } & \multicolumn{2}{c}{ May } & \multicolumn{2}{c}{ June } & \multicolumn{2}{c}{ July } & \multicolumn{2}{c}{ August } & \multicolumn{2}{c}{ September } \\
\cline { 2 - 11 } & Early & Late & Early & Late & Early & Late & Early & Late & Early & Late \\
\hline $\begin{array}{c}\text { Leaf area per } \\
\text { plant }\left(\mathrm{cm}^{2}\right)\end{array}$ & 0 & 130.32 & 891.13 & 2674.03 & 5184.53 & 6104.63 & 6361.67 & 6281.12 & 6053.55 & 5737.3 \\
leaf area index & 0 & 0.05 & 0.21 & 0.70 & 1.46 & 1.72 & 1.83 & 1.80 & 1.70 & 1.57 \\
\hline
\end{tabular}

The Feddes model was used to estimate the water uptake function of the root system. The parameter values of the Feddes model for the root system growth process obtained from Li [41] are shown in Table 6.

Table 6. Feddes parameters (the $\mathrm{h}_{1}$ to $\mathrm{h}_{4}$ values refer to the sink terms proposed by Feddes et al. [42]).

\begin{tabular}{ccccccc}
\hline $\left.\mathbf{h}_{\mathbf{1}} \mathbf{( c m}\right)$ & $\mathbf{h}_{\mathbf{2}} \mathbf{( c m )}$ & $\left.\mathbf{h}_{\mathbf{3}} \mathbf{( c m}\right)$ & $\mathbf{h}_{\mathbf{3}}{ }^{\prime}(\mathbf{c m})$ & $\mathbf{h}_{\mathbf{4}}(\mathbf{c m})$ & $\mathbf{r}_{\mathbf{2 H}}(\mathbf{c m} /$ Day) & $\mathbf{r}_{\mathbf{2 L}}(\mathbf{c m} /$ Day) \\
\hline-1 & -25 & -200 & -800 & -8000 & 0.5 & 0.1 \\
\hline
\end{tabular}

Note: The values of $h_{2}$ and $h_{3}$ represent the thresholds between which water uptake is assumed maximum, while $h_{1}$ and $h_{4}$ represent the oxygen deficiency thresholds due to soil saturation and the minimum soil water content observed in the core of the root system, respectively. The value of $h_{3}$ depends on the transpiration rate $\left(\mathrm{r}_{2 \mathrm{H}}, \mathrm{r}_{2 \mathrm{~L}}\right)$. Thus, $h_{3}$ was taken equal to $-200\left(h_{3}\right)$ and $-800 \mathrm{~cm}\left(h_{3}{ }^{\prime}\right)$ for transpiration rates of 0.5 and $0.1 \mathrm{~cm} \cdot$ day $^{-1}$, respectively.

The bare soil evaporation according to the modified Penman equation [43] is given as follows:

$$
\begin{gathered}
\mathrm{E}_{s}=\frac{\left(R_{n}-G\right) \Delta+\rho_{a} C_{p} \delta e / r_{a}}{\lambda(\Delta+\gamma / \beta)} \\
\beta= \begin{cases}0 & \theta \leq \theta_{m} \\
\frac{1}{4}\left\{1-\cos \left[\frac{\pi\left(\theta-\theta_{m}\right)}{\left(\theta_{f c}-\theta_{m}\right)}\right]\right\}^{2} & \begin{array}{l}
\theta_{m}<\theta<\theta_{f c} \\
1
\end{array} \\
\theta \geq \theta_{f c}\end{cases}
\end{gathered}
$$

where $\rho_{a}$ is the air density $\left(\mathrm{kg} \cdot \mathrm{m}^{-3}\right), C_{p}$ is the specific heat capacity of air $\left(\mathrm{MJ} \cdot \mathrm{m}^{-2} \cdot \mathrm{day}^{-1}\right), \lambda$ is the latent heat of vaporization of water $\left(\mathrm{MJ} \cdot \mathrm{kg}^{-1}\right), \gamma$ is $C / \lambda, \beta$ is the soil water function or efficiency of evaporation, $\theta$ is the volume of the surface soil water, $\theta_{f c}$ is the field soil water retention rate and $\theta_{m}$ is single molecule suction ( $\mathrm{pF}$ 6.0-7.0), which corresponds to the soil volumetric water content [44].

\subsection{Groundwater Level Change Scenarios}

The groundwater depth increases and decreases from $4 \mathrm{~m}$ at a uniform rate, and the monthly fluctuations from 1988 to 1997 based on the data measured at the Changzhuang measuring station were applied in the model. Three model test scenarios with different groundwater levels were selected for a comparative model analysis. In Scenario 1, the groundwater level decreased from 4 to $1.5 \mathrm{~m}$; in Scenario 2, the groundwater level remained stable; and, in Scenario 3, the groundwater level increased from 4 to $10 \mathrm{~m}$.

The nitrate nitrogen content at the groundwater interface was assumed negligible because it was low $\left(1.29,0.71\right.$, and $1.03 \mathrm{mg} \cdot \mathrm{L}^{-1}$ at three different times during the experiment).

\section{Results and Discussion}

The soil water content and nitrate nitrogen concentrations were analyzed every $50 \mathrm{~cm}$ in the vadose zone, ranging from 0 to $4 \mathrm{~m}$, on 1 January 2011. The results obtained from this analysis were used as the initial conditions to simulate soil water and nitrate nitrogen transport. 


\subsection{The Dynamic Responses of Moisture and Nitrate Nitrogen in the Vadose Zone}

This study used calculations to simulate soil water movement based on three model test scenarios with different types of changes in groundwater levels predicted over 10 years and calculated the soil water contents at different depths, as well as the water storage values at different depths in the vadose zone. The simulation results for the three types of groundwater level changes are presented in Figures 7 and 8 .

Figure 7 shows that when the groundwater level drops, the overall soil water content significantly decreases. Greater reductions in groundwater level correspond to greater decreases in the soil water content, and the soil water content increases when the groundwater level increases.

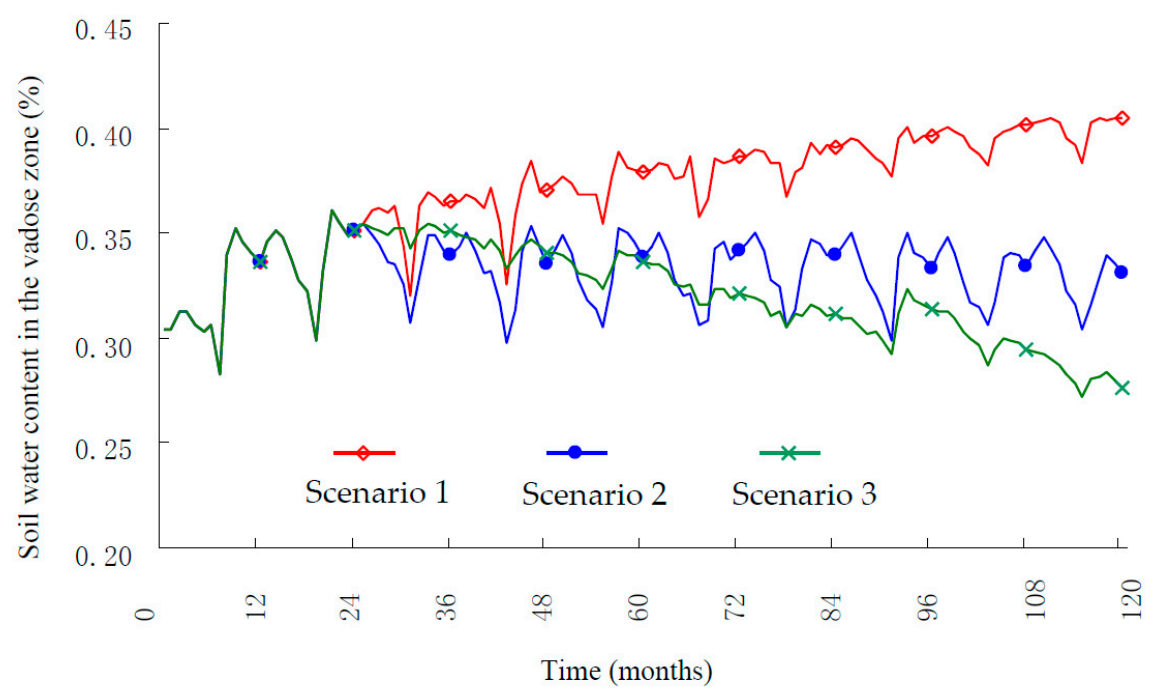

Figure 7. The water content in the vadose zone.

Figure 8 shows that the storage capacity of the entire vadose zone increases as the groundwater level decreases because the unsaturated zone becomes thicker and the water storage space increases. By contrast, when the groundwater depth increases from 4 to $10 \mathrm{~m}$ and the vadose zone thickness increases to $6 \mathrm{~m}$, the amount of water stored in the vadose zone increases by approximately 2.3-fold from 2011 to 2020 . If the groundwater depth is reduced from 4 to $1.5 \mathrm{~m}$, the vadose zone is $2.5 \mathrm{~m}$ thinner, and its water storage capacity would decrease by approximately 50\% from 2011 to 2050 .

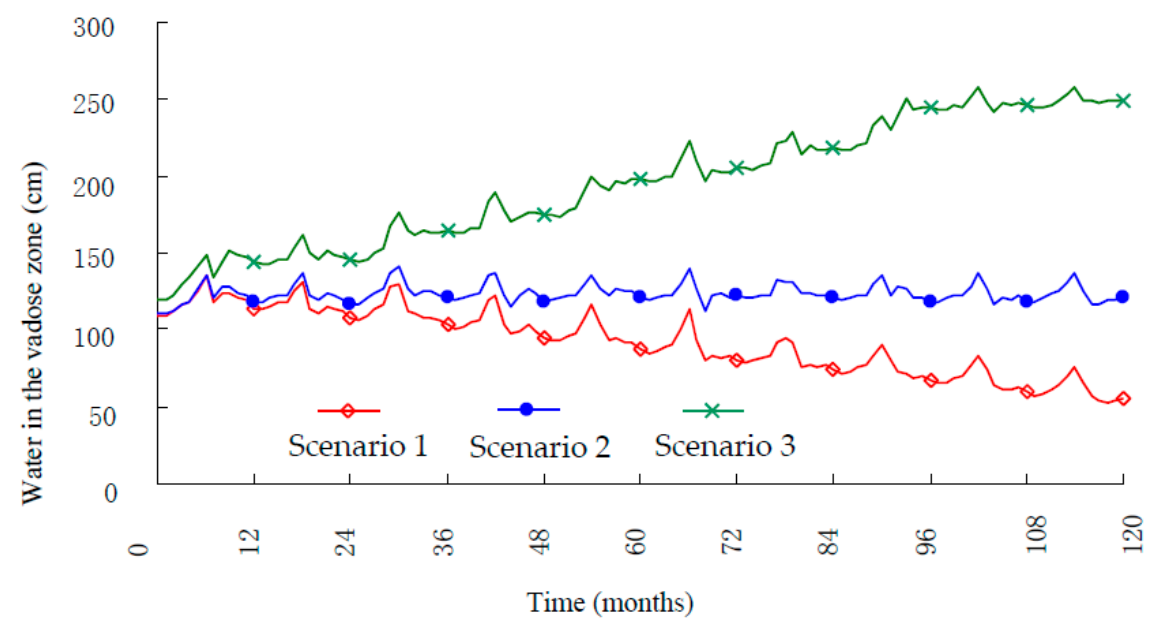

Figure 8. Monthly water storage in the unsaturated zone. 


\subsection{Nitrate Nitrogen Reserves in the Vadose Zone}

The simulation results of the transport and transformation of soil nitrate nitrogen in the three groundwater level change scenarios over 10 years reveal the nitrate nitrogen concentrations at different depths and the nitrate nitrogen reserves throughout the vadose zone (Figures 9 and 10).

Regardless of whether the groundwater level decreases, remains constant or increases, the nitrate nitrogen concentration increases with time (Figure 9).

All nitrate nitrogen reserves in the vadose zone gradually increase in response to the application of excess fertilizer, regardless of whether the groundwater level decreases, remains constant or increases in the first five years (Figure 10).

In the last five years that were modeled, the nitrate nitrogen reserves changed differently in the different scenarios and in the presence of different groundwater levels.

The nitrate nitrogen reserves increased when the groundwater depth was stable and decreased when the thickness of the vadose zone increased. When the groundwater depth was changed from 4 to $10 \mathrm{~m}$, the thickness of the vadose zone increased to $6 \mathrm{~m}$, and the nitrate nitrogen reserves in the vadose zone increased by 2.6-fold after ten years.

If the groundwater depth is increased from 4 to $1.5 \mathrm{~m}$, the thickness of the vadose zone gradually decreases, and the nitrate nitrogen reserves of the vadose zone peak in 2016 at a concentration of nearly twice the concentration observed in 2011 before decreasing thereafter. The nitrate nitrogen reserves in the vadose zone in 2020 are nearly equal to those in 2011 due to the combination of the positive and negative effects of over-fertilization, and the nitrate nitrogen in the lower vadose zone dissolves into the groundwater as the groundwater level increases.

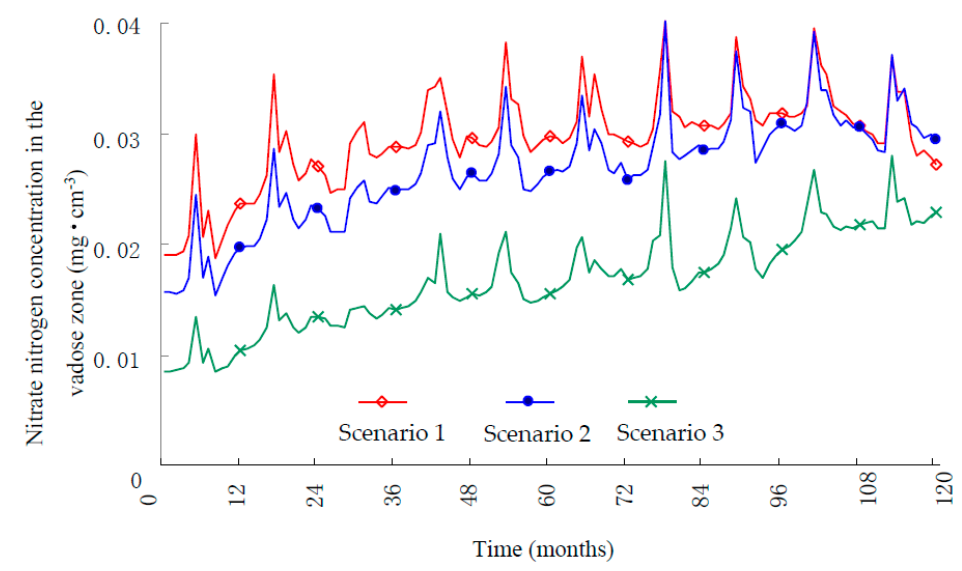

Figure 9. The nitrate nitrogen concentrations at different depths in the vadose zone over time.

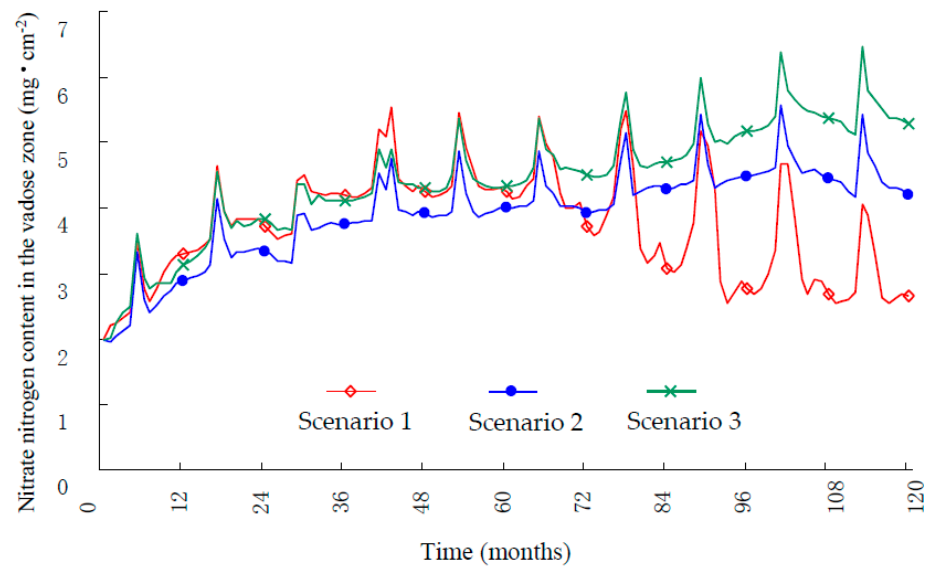

Figure 10. The nitrate nitrogen reserves throughout the vadose zone over time. 


\subsection{The Leaching Capacity of Nitrate Nitrogen}

Figure 11 shows the amount of nitrate nitrogen that leached into the groundwater from the vadose zone each year for the three scenarios of groundwater level change.

Figure 11 shows that leaching increased as the groundwater level increased. This result does not include the amount of dissolved nitrate nitrogen due to the increasing groundwater level. If the groundwater level is constant or decreases, the concentration of leached nitrate nitrogen is low enough to neglect.

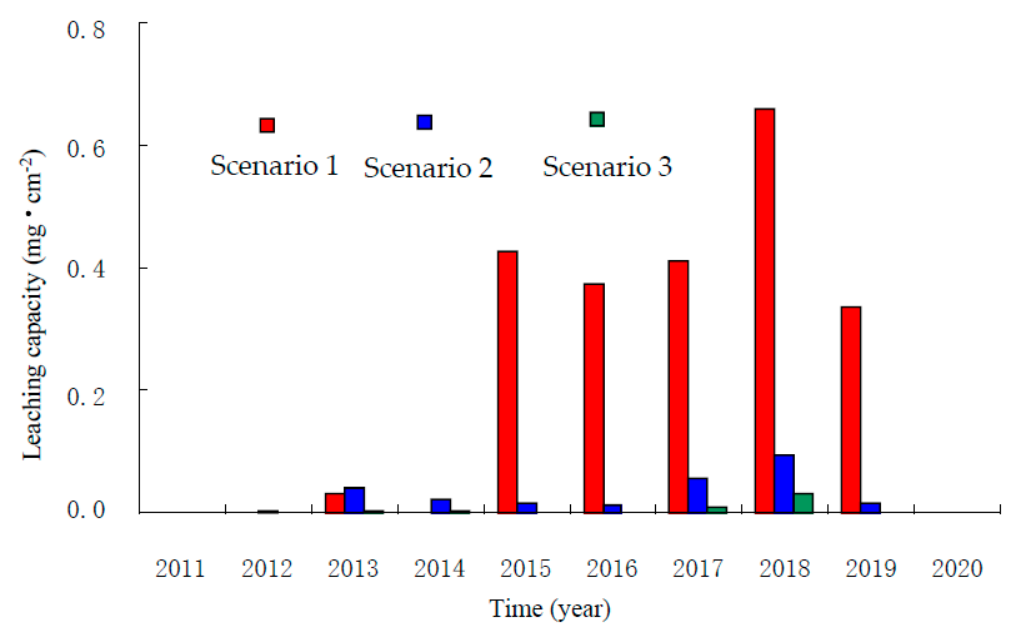

Figure 11. The amount of nitrate nitrogen leached into the vadose zone.

\subsection{Deep Percolation of Soil Water in the Root Zone}

Deep percolation is a hydrologic process in which water moves downward from the surface in the root zone to deeper groundwater due to precipitation or irrigation levels that exceed the soil water holding capacity. Deep percolation results in moisture and nutrient loss. A reasonable irrigation strategy should be used to minimize deep percolation. A simulation of soil water movement was conducted in this study for the scenarios of groundwater level change predicted over the 10-year period, and the percolation of water in the cotton root zone was assessed. The results are shown in Figure 12.

Deep percolation in the root zone was largely dependent on yearly precipitation (Figure 12). Deep percolation increased with greater precipitation and increased groundwater depth, primarily because deeper groundwater causes higher suction below the root zone and faster water flow.

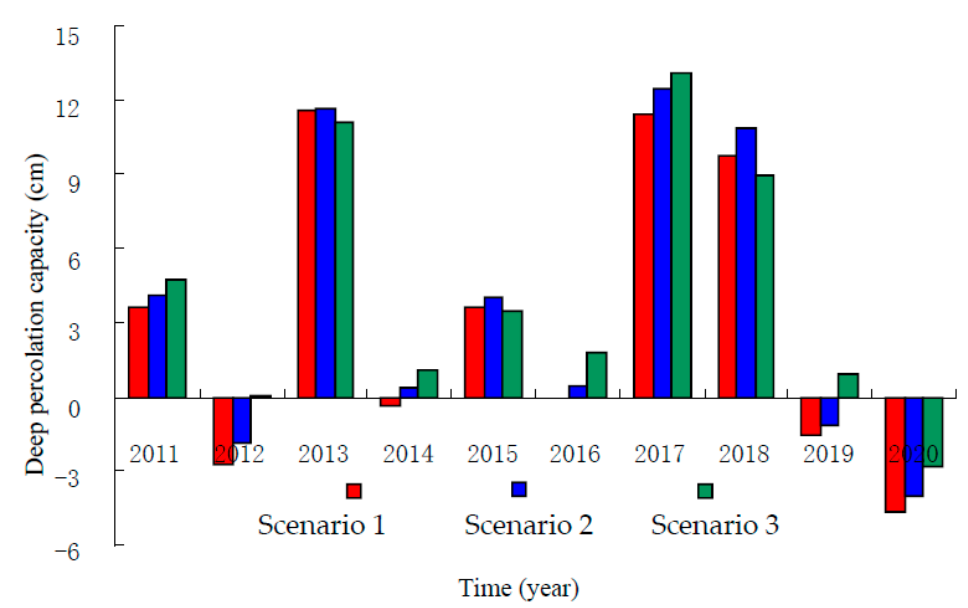

Figure 12. The deep percolation capacity of the root zone $(60 \mathrm{~cm})$ of cotton. 


\subsection{The Leaching Capacity of Nitrate Nitrogen in the Root Zone}

The results for the three scenarios of the simulated changes in groundwater level over the 10-year period and the amount of leaching in the root zone are shown in Figure 13.

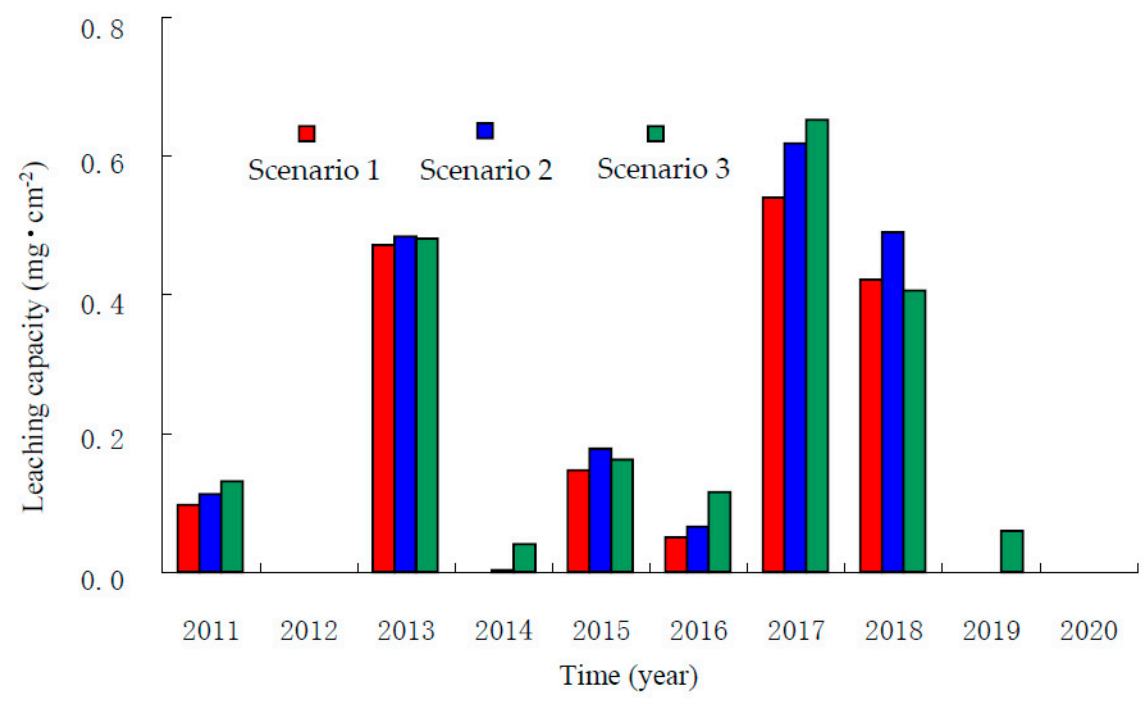

Figure 13. Leaching of the nitrate nitrogen reserves in the root zone $(60 \mathrm{~cm})$ of cotton.

Greater precipitation and a deeper groundwater level correspond to greater leaching of nitrate nitrogen and deep percolation of the soil water in the root zone (Figure 13).

\section{Conclusions}

The groundwater level in Heilonggang Basin, Hebei Province, China, has continuously decreased in recent decades. Based on a soil water movement simulation and the transport and transformations of soil nitrate nitrogen under three groundwater level scenarios predicted in a 10-year period, the impacts of groundwater changes in the vadose zone of a cotton field on the accumulation and distribution of nitrate nitrogen were studied. The following conclusions were drawn from the results.

(1) If the groundwater level remains stable or decreases, the accumulation of nitrate nitrogen in the groundwater at any depth is substantial. As the groundwater level increases, the amount of nitrate accumulation increases. Nitrate nitrogen in the vadose zone initially accumulates and then decreases because part of the accumulated nitrate nitrogen dissolves and pollutes the groundwater, which is a complex result of over-fertilization and the dissolution of nitrate nitrogen in the lower part of the vadose zone into the groundwater due to rising groundwater levels. Therefore, over-fertilization results in the accumulation of nitrate nitrogen in the vadose zone. As the groundwater level decreases, the amount of nitrate leaching into the groundwater decreases. However, if the groundwater level increases, some of the accumulated nitrate nitrogen will contaminate the groundwater as a result of its dissolution.

(2) As precipitation increases and the groundwater level increases, the amount of nitrate nitrogen leached from the cotton root zone increases, which is related to the deep percolation of soil water. Consequently, irrigation and fertilization strategies should be adjusted to account for different precipitation and groundwater levels to reduce deep percolation from the cotton root zone and the leaching of fertilizer and improve the efficiency of water and nitrogen fertilizer use. 
Acknowledgments: This work was financially supported by the National Natural Science Foundation of China (50979025).

Author Contributions: Mohamed Khaled Salahou and Xiyun Jiao conceived and designed the experiment, performed the analysis, analyzed the data, produced the tables and wrote the paper. Arkin Maimaitiyiming, Kaihua Liu and Weihua Guo performed the experiment and collected the data. Mohamed Khaled Salahou, Xiyun Jiao, Kaihua Liu, Arkin Maimaitiyiming and Weihua Guo all read and made improvements to the manuscript.

Conflicts of Interest: The authors declare no conflict of interest.

\section{References}

1. Li, X.; Li, G.; Zhang, Y. Identifying major factors affecting groundwater change in the north China plain with grey relational analysis. Water 2014, 6, 1581-1600. [CrossRef]

2. Zhang, X.; Zhang, L.; He, C.; Li, J.; Jiang, Y.; Ma, L. Quantifying the impacts of land use/land cover change on groundwater depletion in Northwestern China-A case study of the Dunhuang oasis. Agric. Water Manag. 2014, 146, 270-279. [CrossRef]

3. Bai, J.; Zhang, G.P. Cangzhou City adopts many measures to exploit groundwater. China Water Resour. 2010, 17, 28-30.

4. Qin, T.C. The relationship between groundwater exploitation and land subsidence in Cangzhou. Technol. Soil Water Conserv. 2010, 1, 39-41.

5. Xu, Y.; Mo, X.; Cai, Y.; Li, X. Analysis on groundwater table drawdown by land use and the quest for sustainable water use in the Hebei Plain in China. Agric. Water Manag. 2005, 75, 38-53. [CrossRef]

6. Dai, J.; Xu, G.M.; Du, X.M.; Dai, Y.K.; Jian, M.; Li, H.X. Reasonable development and utilization of shallow underground water resources in Cangzhou City. Yangtze River 2008, 39, 40-42.

7. Wang, C.M. Research on exploitation and utilization of shallow groundwater inside plain containing saline-water. J. Yangtze River Sci. Res. Inst. 2009, 26, 118-122.

8. China Statistics Publishing House. Hebei Rural Statistical Yearbook 1991-2007; China Statistics Publishing House: Beijing, China, 2007.

9. Li, B.G.; Bai, Y.L.; Hu, K.L.; Huang, Y.F.; Chen, D.L. Spatial variability and distribution characteristics of $\mathrm{NO}_{3}-\mathrm{N}$ of shallow ground water in the North China Plain. China Eng. Sci. 2001, 3, 42-45. (In Chinese)

10. Zhang, W.; Tian, Z.; Zhang, N.; Li, X. Nitrate pollution of groundwater in northern China. Agric. Ecosyst. Environ. 1996, 59, 223-231. [CrossRef]

11. US Environmental Protection Agency (USEPA). Drinking-Water Regulations and Health Advisories; Office of Water, US Environmental Protection Agency: Washington, DC, USA, 1995.

12. Water Quality Branch. Canadian Water Quality Guidelines; Inland Waters Directorate: Ottawa, ON, Canada, 1995.

13. Kundu, M.C.; Mandal, B. Agricultural activities influence nitrate and fluoride contamination in drinking groundwater of an intensively cultivated district in India. Water Air Soil Pollut. 2009, 198, 243-252. [CrossRef]

14. Dimitriou, I.; Aronsson, P. Nitrogen leaching from short-rotation willow coppice after intensive irrigation with wastewater. Biomass Bioenergy 2004, 26, 433-441. [CrossRef]

15. Zhao, B.-Z.; Zhang, J.-B.; Flury, M.; Zhu, A.-N.; Jiang, Q.-A.; Bi, J.-W. Groundwater contamination with $\mathrm{NO}_{3}-\mathrm{N}$ in a wheat-corn cropping system in the North China Plain. Pedosphere 2007, 17, 721-731. [CrossRef]

16. Zhu, Z.; Chen, D. Nitrogen fertilizer use in China-Contributions to food production, impacts on the environment and best management strategies. Nutr. Cycl. Agroecosyst. 2002, 63, 117-127. [CrossRef]

17. Zhang, Y.; Zhang, S.; Liu, C.L.; Hou, H.B. Fertilization and nitrogen accumulation in shallow soil of the field. Soils 2006, 38, 92-98.

18. Zhang, S.; Zhang, Y.; Zhang, F.E.; Jing, J.H. Experimental study of microecological remediation of soils in the nitrate-contaminated aeration zone. Reg. Geol. China 2004, 23, 1109-1112.

19. Kong, F.R. The Utilization Efficiency Experiment and Simulation Evaluation of Soil Water and Fertilizer under Different Groundwater Buried Depth, Inner Mongolia; Agricultural University: Beijing, China, 2009.

20. Magesan, G.; McLay, C.; Lal, V. Nitrate leaching from a free-draining volcanic soil irrigated with municipal sewage effluent in New Zealand. Agric. Ecosyst. Environ. 1998, 70, 181-187. [CrossRef] 
21. Zhang, Y.; Zhang, S.; Liu, C.L.; Hou, H.B.; Dong, H.; Zhang, M. Prospect of capability of aeration zone in soil in prevention nitrogen from pollution of groundwater. J. Agro-Environ. Sci. 2006, 25, 339-346.

22. Wang, Q.; Fengrui, L.; Lin, Z.; Enhe, Z.; Shangli, S.; Wenzhi, Z.; Weixin, S.; Vance, M.M. Effects of irrigation and nitrogen application rates on nitrate-nitrogen distribution and fertilizer nitrogen loss, wheat yield and nitrogen uptake on a recently reclaimed sandy farmland. Plant Soil 2010, 337, 325-339. [CrossRef]

23. Xu, L.; Zhang, Q.; Huang, L. Nitrogen leaching in a typical agricultural extensively cropped catchment, China: Experiments and modelling. Water Environ. J. 2010, 24, 97-106. [CrossRef]

24. Kang, Y.H. Experimental Study on $\mathrm{NO}_{3}-\mathrm{N}$ Deep Migration in Loess Plateau of Aerated Zone under Irrigation Condition. Master's Thesis, Northwest A \& F University, Shaanxi, China, 2006.

25. Ritter, A.; Muñoz-Carpena, R.; Bosch, D.D.; Schaffer, B.; Potter, T.L. Agricultural land use and hydrology affect variability of shallow groundwater nitrate concentration in South Florida. Hydrol. Process. 2007, 21, 2464-2473. [CrossRef]

26. Somura, H.; Goto, A.; Matsui, H.; Ali Musa, E. Impacts of nutrient management and decrease in paddy field area on groundwater nitrate concentration: A case study at the Nasunogahara alluvial fan, Tochigi Prefecture, Japan. Hydrol. Process. 2008, 22, 4752-4766. [CrossRef]

27. Dragon, K. Groundwater nitrate pollution in the recharge zone of a regional Quaternary flow system (Wielkopolska region, Poland). Environ. Earth Sci. 2012, 68, 2099-2109. [CrossRef]

28. Wang, H.; Gao, J.-E.; Li, X.-H.; Zhang, S.-L.; Wang, H.-J. Nitrate accumulation and leaching in surface and ground water based on simulated rainfall experiments. PLoS ONE 2015, 10, e0136274. [CrossRef] [PubMed]

29. Ventrella, D.; Losavio, N.; Mohanty, B.P. Using the HYDRUS-1D model for simulating chloride transport in a clayey soil in presence of shallow groundwater: Sensitivity analysis. In Proceedings of the Modelling of Transport Processes in Soils at Various Scales in Time and Space, Leuven, Belgium, 24-26 November 1999.

30. Van Genuchten, M.T. A closed-form equation for predicting the hydraulic conductivity of unsaturated soils. Soil Sci. Soc. Am. J. 1980, 44, 892-898. [CrossRef]

31. Mualem, Y. A new model for predicting the hydraulic conductivity of unsaturated porous media. Water Resour. Res. 1976, 12, 513-522.

32. Stumpp, C.; Engelhardt, S.; Hofmann, M.; Huwe, B. Evaluation of pedotransfer functions for estimating soil hydraulic properties of prevalent soils in a catchment of the Bavarian Alps. Eur. J. For. Res. 2009, 128, 609-620. [CrossRef]

33. Jellali, S.; Diamantopoulos, E.; Kallali, H.; Bennaceur, S.; Anane, M.; Jedidi, N. Dynamic sorption of ammonium by sandy soil in fixed bed columns: Evaluation of equilibrium and non-equilibrium transport processes. J. Environ. Manag. 2010, 91, 897-905. [CrossRef] [PubMed]

34. Šimůnek, J.; van Genuchten, M.T. Modeling nonequilibrium flow and transport processes using HYDRUS. Vadose Zone J. 2008, 7, 782-797. [CrossRef]

35. Wang, K. Soil Water Movement and Solute Transport in the Aeration Zone; Science Press: Beijing, China, 2010.

36. Zeng, L.H.; Song, K.S.; Zhang, B.; Wang, Z.M.; Liu, D.W.; Du, J. Reference evapotranspiration change and its influencing factors in Songnen Plain. Syst. Sci. Compr. Stud. Agric. 2010, 26, 41-48.

37. Droogers, P.; Allen, R.G. Estimating reference evapotranspiration under inaccurate data conditions. Irrig. Drain. Syst. 2002, 16, 33-45. [CrossRef]

38. Yang, J.; Li, B.; Shiping, L. A large weighing lysimeter for evapotranspiration and soil-water-groundwater exchange studies. Hydrol. Process. 2000, 14, 1887-1897. [CrossRef]

39. Jones, C.A.; Kiniry, J.R.; Dyke, P. CERES-Maize: A Simulation Model of Maize Growth and Development; Texas A \& M University Press: College Station, TX, USA, 1986

40. Li, S.; Kang, S.; Li, F.; Zhang, L. Evapotranspiration and crop coefficient of spring maize with plastic mulch using eddy covariance in northwest China. Agric. Water Manag. 2008, 95, 1214-1222. [CrossRef]

41. Li, M. Numerical Modeling of Water and Salt Movement and Drainage System. Ph.D. Thesis, Hohai University, Nanjing, China, 2004. (In Chinese)

42. Feddes, R.A.; Kowalik, P.J.; Zaradny, H. Simulation of Field Water Use and Crop Yield; Pudoc: Wageningen, The Netherlands, 1978. 
43. Jia, Y.; Tamai, N. Modeling infiltration into a multi-layered soil during an unsteady rain. J. Hydraul. Eng. 1997, 41, 31-36. [CrossRef]

44. Nagaegawa, T. A Study on Hydrological Models Which Consider Distributions of Physical Variables in Heterogeneous Land Surface. Ph.D. Thesis, University of Tokyo, Tokyo, Japan, 1996. (In Japanese)

(c) 2017 by the authors. Licensee MDPI, Basel, Switzerland. This article is an open access article distributed under the terms and conditions of the Creative Commons Attribution (CC BY) license (http:/ / creativecommons.org/licenses/by/4.0/). 